\title{
Chromosome numbers in some alien plant species of Novosibirsk Region (Novosibirsk city): post I
}

\author{
T. V. An’kova, E. Yu. Zykova \\ Federal State Institution of Science Central Siberian Botanical Garden of Siberian Branch of RAS, Zolotodolinskaya str., 101, \\ Novosibirsk,630090,Russian Federation.E-mail: ankova_tv@mail.ru
}

Keywords: diploid, invasive species, mixoploid, Novosibirsk Region, polyploid, vascular plants.

Summary. Chromosome numbers ( $2 n$ ) for 14 alien species (Apiaceae, Asteraceae, Brassicaceae, Commelinaceae, Fabaceae, Onagraceae, Poaceae) from the Novosibirsk city (Akademgorodok) are represented. For the first time the chromosome number is counted for Silphiodaucus hispidus (M. Bieb.) Spalik, Wojew., Banasiak, Piwczyński et Reduron $(2 n=22)$ in Russia; for Cardamine flexuosa With. $(2 n=32)$, Commelina communis L. $(2 n \approx 48)$, Astragalus falcatus Lam. $(2 n=16)$, Lathyrus sylvestris L. $(2 n=14)$, Oenothera rubricaulis Klebahn, $(2 n=14)$ in Siberia; for Raphanus raphanistrum L. $(2 n=18)$ in West Siberia; for Centaurea jacea L. $(2 n=44)$, Erigeron canadensis L. $(2 n=$ $18)$, Sonchus asper (L.) Hill. $(2 n=18)$, Sisymbrium officinale (L.) Scop. $(2 n=14)$, Lolium multiflorum Lam. $(2 n=14)$ in Novosibirsk Region. All species are provided with the brief information on their general spreading and distribution in Novosibirsk Region, as well as literature data on chromosome numbers.

\section{Числа хромосом некоторых чужеродных видов растений Новосибирской области (г. Новосибирск): сообщение 1}

\author{
Т. В. Анькова, Е. Ю. Зыкова
}

\begin{abstract}
Федеральное государственное бюджетное учреждение науки «Центральный сибирский ботанический сад» Сибирского отделения РАН, ул. Золотодолинская, 101, г. Новосибирск, 630090, Россия
\end{abstract}

Ключевые слова: диплоид, инвазивные виды, миксоплоид, Новосибирская область, полиплоид, сосудистые растения.

Аннотация. Приводятся числа хромосом (2n) для 14 чужеродных видов семейств Apiaceae, Asteraceae, Brassicaceae, Commelinaceae, Fabaceae, Onagraceae, Pоасеае из Академгородка (г. Новосибирск, Советский район). Впервые для России определено число хромосом Silphiodaucus hispidus (M. Bieb.) Spalik, Wojew., Banasiak, Piwczyński et Reduron $(2 n=22)$; впервые для Сибири - Cardamine flexиosa With. $(2 n=32)$, Commelina communis L. $(2 n \approx 48)$, Astragalus falcatus Lam. $(2 n=16)$, Lathyrus sylvestris L. $(2 n=14)$, Oenothera rubricaulis Klebahn, $(2 n=14)$; впервые для Западной Сибири - Raphanus raphanistrum L. $(2 n=18)$; впервые для Новосибирской области -Centaurea jacea L. $(2 n=44)$, Erigeron canadensis L. $(2 n=18)$, Sonchus asper (L.) Hill. $(2 n=$ 18), Sisymbrium officinale (L.) Scop. $(2 n=14)$, Lolium multiflorum Lam. $(2 n=14)$. Для всех исследованных видов приводятся краткие сведения по общему распространению и расселению в Новосибирской области, литературные данные по числам хромосом.

Studying the polyploidy phenomenon, which existence supposed to contribute the species viability by some authors (Breslavets, 1963; Stebbins, 1985; Probatova, 2003; Soltis et al.,
2010), we start investigating the chromosome numbers of alien flora species in Novosibirsk Region. The first communication represents data on 14 species (Apiaceae, Asteraceae, Brassicaceae, 
Commelinaceae, Fabaceae, Onagraceae, Poaceae), seven of them are active either at the whole territory of the Novosibirsk Region, or in only single habitats newly discovered recently.

We collected the seeds and herbarium material in situ from Akademgorodok (Novosibirsk city, Sovetsky district). The chromosome numbers were determined according to the standard approach: the karyological analysis was made on root meristem squash preparations from seedlings. Seeds were germinated in Petri dishes on wet sterile sand at 27 ${ }^{\circ} \mathrm{C}$ and light regime providing of 16 hours of daylight and eight hours of darkness. The germs were treated in $0.2 \%$ colchicine for two hours and then fixed in a mixture of ethanol acetic acid $(3: 1)$. The chromosomes were stained with acetohaematoxylin according to Smirnov (1968). Slides were examined under Axioscop-40 microscope. We conducted the chromosome analyses on 5-10 slides under 100× magnification. Vouchres are stored in the Herbarium of the Central Siberian Botanical Garden of Siberian Branch of the Russian Academy Sciences (NS, Novosibirsk).

\section{APIACEAE}

Silphiodaucus hispidus (M. Bieb.) Spalik, Wojew., Banasiak, Piwczyński et Reduron (Laserpitium hispidum M. Bieb.), $2 \boldsymbol{n}=\mathbf{2 2}$

"Novosibirsk Region, Novosibirsk city, the Central Siberian Botanical Garden, old overgrown sites, $54^{\circ} 50^{\prime} \mathrm{N}, 83^{\circ} 06^{\prime} \mathrm{E} .9$ X 2017. E. Zykova, T. Shemetova", 7517-Z411 (fig. 1A).

Distribution: Caucasus, Asia Minor, southern regions of East Europe, from it is spread to central parts of European Russia. In Siberia it's known only in Novosibirsk Region, here it was first discovered in 2013 (Zykova et al., 2014a). In the revealed habitats it's active, expands the area of populations. The same number is indicated for the Ukraine and Turkey (Rice et al., 2015). We give the first data on chromosome number for Russia.

Diploid $(2 x), x=11$.

\section{ASTERACEAE}

\section{Centaurea jacea L., $2 n=44$}

"Novosibirsk Region, Novosibirsk city, Nikolaev street, Technopark, along roads, $54^{\circ} 50^{\prime} \mathrm{N}, 83^{\circ} 06^{\prime} \mathrm{E}$. 1 VIII 2017. E. Zykova", 3917-Z483 (fig. 1B).

Distribution: European-Mediterranean species with Holarctic secondary distribution. The first finding in Novosibirsk Region was recorded in 1970s (Zykova, 2016); by now, the species has spread widely throughout the region (Zykova, 2019). It is included in the Black Book of Siberia (Zykova, 2016) and in the list of invasive and potentially invasive species (Ebel et al., 2014). The same chromosome number was reported first for Siberia on specimens of the Republic of Altai (Zykova et al., 2018). Only tetraploid strain is known for Russia (Tonyan, 1968; Probatova et al., 2008). We give the first data on chromosome number for Novosibirsk Region.

Tetraploid ( $4 x), x=11$. Variable ploidy.

\section{Cota tinctoria (L.) J. Gay (Anthemis tinctoria} L.), $2 n=18$

"Novosibirsk Region, Novosibirsk city, «Shlyuz» micro-district, wasteland along a narrow-gauge road, $54^{\circ} 50^{\prime} \mathrm{N}, 83^{\circ} 06^{\prime}$ E. 2 VIII 2017. E. Zykova, T. Shemetova", 4417-Z454.

Distribution: European species was settled to Eurasia; marked in most parts of Novosibirsk Region (Zykova, 2019). The same number was determined first for Siberia at the Central Siberian Botanical Garden surroundings by T. Rostovtseva (1983). Diploid and tetraploid strain were identified first for the Republic of Altai (An'kova, Zykova, 2017).

Diploid $(2 x), x=9$. Variable ploidy.

Erigeron canadensis L. (Conyza canadensis (L.) Cronq.) $2 n=18$

"Novosibirsk Region, Novosibirsk city, Tereshkova street, houses' yards, outside lawns and flower beds, $54^{\circ} 50^{\prime} \mathrm{N}, 83^{\circ} 06^{\prime}$ E. 30 VII 2017. E. Zykova", 3817-Z375 (fig. 1C).

Distribution: North American native species, as invasive one is cosmopolite. It is known in the Novosibirsk Region since 1932 (Antipova, 2016), now is common in the region (Zykova, 2019). It is included in the Black Book of Siberian flora (Antipova, 2016) and in the list of invasive and potentially invasive species (Ebel et al., 2014). The same chromosome number was reported for Siberia on specimens from Republic of Buryatia, Irkutsk Region (Chepinoga, 2014), Kurgan Region (Krasnikov, Korolyuk, 1995) and Republic of Altai (Lomonosova et al., 2018). Tetra- and hexaploid chromosomal strains of this species are observed in Portugal, India and Canada (Rice et al., 2015). We give the first data on chromosome number for Novosibirsk Region.

Diploid $(2 x), x=9$. Variable ploidy.

\section{Sonchus asper (L.) Hill., $2 n=18$}

"Novosibirsk Region, Novosibirsk city, the Central Siberian Botanical Garden, weeds in greenhouses, $54^{\circ} 50^{\prime} \mathrm{N}, 83^{\circ} 06^{\prime} \mathrm{E}$. $25 \mathrm{~V}$ 2017. E. Zykova, T. Shemetova", 0317-Z406 (fig. 1D). 
Distribution: Eurasian species. In Novosibirsk Region it is known only from Novosibirsk city (Zykova et al., 2014b; Zykova, 2019). It was determined for the first time for West Siberia on Republic of Altai: $2 n=18$ and $2 n=32$ (An'kova,
Zykova, 2017). Diploid and tetraploid strains are noted for East Siberia (Rice et al., 2015). We give the first data on chromosome number for Novosibirsk Region.

Diploid $(2 x), x=9$. Variable ploidy.

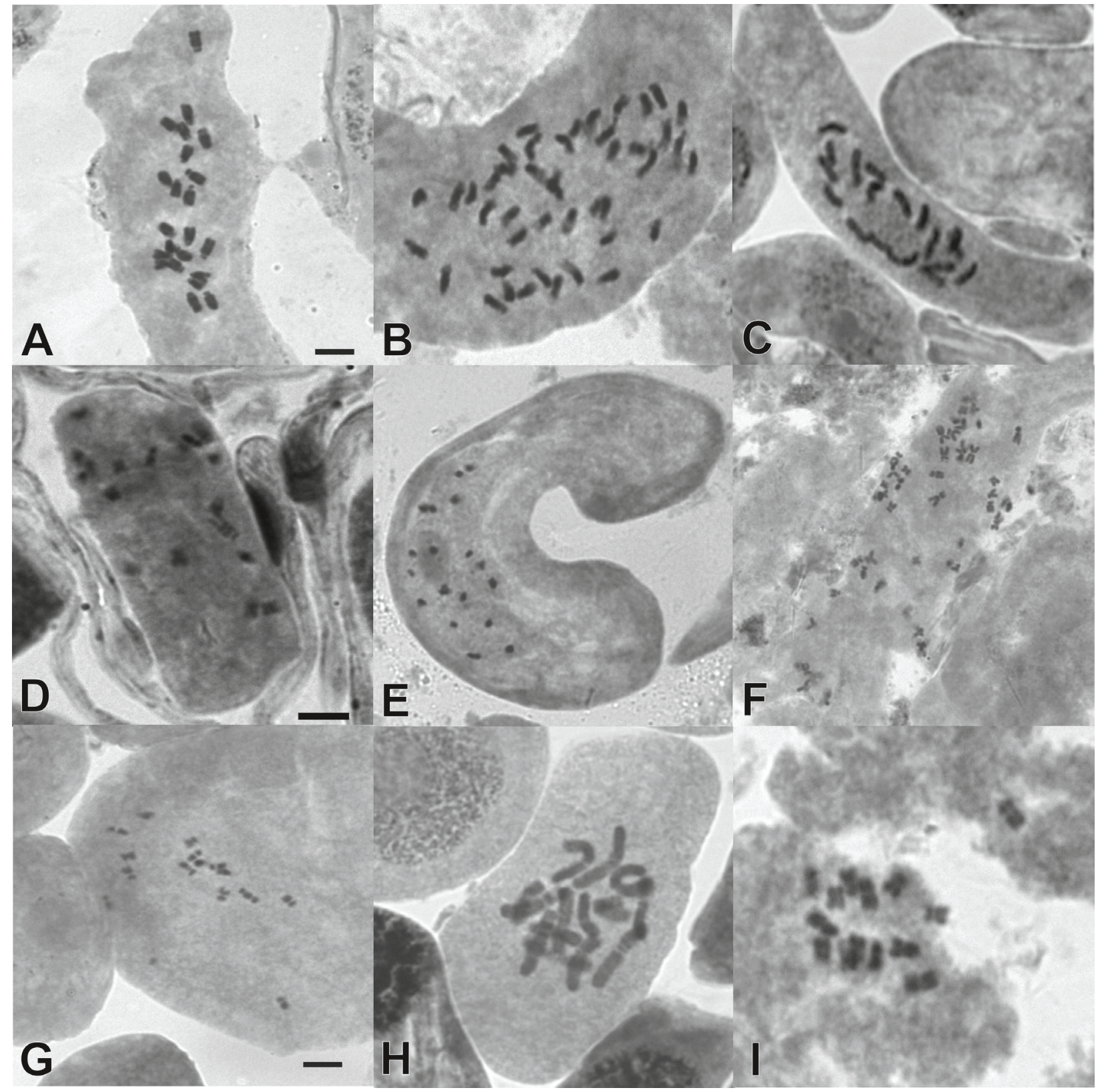

Fig. 1. Mitotic metaphases: A - Silphiodaucus hispidus, $2 n=22 ; \mathrm{B}-$ Centaurea jacea, $2 n=44 ; \mathrm{C}-$ Erigeron canadensis, $2 n=18 ; \mathrm{D}-$ Sonchus asper, $2 n=18 ; \mathrm{E}-$ Raphanus raphanistrum, $2 n=18 ; \mathrm{F}-$ Commelina communis, $2 n \approx 48$; $\mathrm{G}-$ Astragalus falcatus, $2 n=16 ; \mathrm{H}-$ Lathyrus sylvestris, $2 n=14$, I-Oenothera rubricaulis, $2 n=14$. Scale $=5 \mu \mathrm{m}$.

\section{BRASSICACEAE}

Cardamine flexuosa With., $2 n=32$

"Novosibirsk Region, Novosibirsk city, the Central Siberian Botanical Garden, weeds in greenhouses, $54^{\circ} 50^{\prime} \mathrm{N}, 83^{\circ} 06^{\prime} \mathrm{E}$. $25 \mathrm{~V}$ 2017. E. Zykova, T. Shemetova", 0317-Z315.
Distribution: European-Mediterranean species. In Siberia it is known only in Novosibirsk Region; it was discovered in Novosibirsk city in 2010 (Shaulo, Zykova, 2013). We give the first data on chromosome number for Siberia.

Diploid $(2 x), x=16$. 


\section{Raphanus raphanistrum L., $2 n=18$}

"Novosibirsk Region, Novosibirsk city, the Upper Zone, suburban areas along roads, $54^{\circ} 50^{\prime} \mathrm{N}$, $83^{\circ} 06^{\prime}$ E. 2 VIII 2017. E. Zykova, T. Shemetova", 4017-Z371 (fig. 1E).

Distribution: Eurasian weed. It's common in all areas of Novosibirsk Region (Zykova, 2019). The same chromosome number is given for East Siberia (Probatova et al., 2012). We give the first data on chromosome number for West Siberia.

Diploid $(2 x), x=9$.

Sisymbrium officinale (L.) Scop., $2 n=14$

"Novosibirsk Region, Novosibirsk city, «Shlyuz» micro-district, wasteland along a narrow-gauge road, $54^{\circ} 50^{\prime} \mathrm{N}, 8^{\circ} 06^{\prime}$ E. 2 VIII 2017. E. Zykova, T. Shemetova", 4417-Z317.

Distribution: European-Mediterranean-Asia minor species, settled in the world temperate zone. In the Novosibirsk Region is quite rare (Efremov, 2016; Zykova, 2019). It is included in the Black Book of Siberian flora (Efremov, 2016) and in the list of invasive and potentially invasive species of Siberia (Ebel et al., 2014).

The same chromosome number was determined for the first time for Russia on the Republic of Altai (Zykova et al., 2018). We give the first data on chromosome number for Novosibirsk Region.

Diploid $(2 x), x=7$.

\section{COMMELINACEAE}

Commelina communis L. $2 n \approx 48$, the number is unstable

"Novosibirsk Region, Novosibirsk city, vicinity of the Central Beach, railway embankments, $54^{\circ} 50^{\prime}$ N, $83^{\circ} 06^{\prime}$ E. 2 VIII 2017. E. Zykova, T. Shemetova", 4217-Z628 (fig. 1F).

Distribution: Far Eastern species with the secondary Holarctic range; rare in Siberia. In Novosibirsk Region it was discovered in 2017 in Novosibirsk city (Zykova, Shemetova, 2018).

For the first time in Russia, the number of chromosomes $2 n \approx 48$ was determined in Primorye Territory (Probatova, Sokolovskaya, 1986). The chromosome number varies within one individual. We give the first data on chromosome number for Siberia.

Mixoploid.

\section{FABACEAE}

Astragalus cicer L., $2 n=64$

"Novosibirsk Region, Novosibirsk city, the
Upper Zone, suburban areas along roads, $54^{\circ} 50^{\prime} \mathrm{N}$, $83^{\circ} 06^{\prime}$ E. 2 VIII 2017. E. Zykova, T. Shemetova", 4017-Z322.

Distribution: European species; quite rare in Siberia. The first location in Novosibirsk city was fixed in 1998 (Shaulo et al., 2010). It enters the list of invasive and potentially invasive species in Siberia (Ebel et al., 2014). It is noted the same chromosome number as before in the Central Siberian Botanical Garden vicinity (An'kova et al., 2013).

Polyploid $(8 x), x=8$. Variable ploidy.

\section{Astragalus falcatus Lam., $2 n=16$}

"Novosibirsk Region, Novosibirsk city, the Central Siberian Botanical Garden, old overgrown areas, $54^{\circ} 50^{\prime} \mathrm{N}, 83^{\circ} 06^{\prime}$ E. 9 X 2017. E. Zykova, T. Shemetova", 7517-Z625 (fig. 1G).

Distribution: The natural range covers Europe, the Caucasus, Asia Minor. It was withdrawal of culture noted in Novosibirsk Region in 2017 (Zykova, Shemetova, 2018).

In Russia, the same number is specified for the North Caucasus (Stavropol Territory) (Magulaev, 1980). We give the first data on chromosome number for Siberia.

Diploid (2x), $x=8$.

\section{Lathyrus sylvestris L., $2 n=14$}

"Novosibirsk Region, Novosibirsk city, the Central Siberian Botanical Garden, abandoned expositions, $54^{\circ} 50^{\prime} \mathrm{N}, 83^{\circ} 06^{\prime}$ E. 15 X 2017. E. Zykova", 7617-Z389 (fig. 1H).

Distribution: The natural range covers Europe, the Caucasus, the Mediterranean and Asia Minor. It is rare in Siberia, in Novosibirsk Region since 2000; it was found in Iskitim, Novosibirsk districts and Novosibirsk city (Shaulo, Zykova, 2013; Zykova et al., 2014a).

In Russia, the same chromosome number is known only in Ossetia (Efimov, 2005). We give the first data on chromosome number for Siberia.

Diploid $(2 x), x=8$.

\section{ONAGRACEAE}

Oenothera rubricaulis Klebahn (O. biennis auct. non L.), $2 n=14$

"Novosibirsk Region, Novosibirsk city, «Shlyuz» micro-district, wasteland along a narrow-gauge

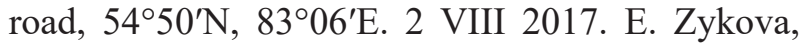
T. Shemetova”, 4417-Z455 (fig. 1I).

Distribution: North American species. It is recently in Siberia compared with other genus species. In Novosibirsk Region it was found in 2012 
in Novosibirsk city (Ebel et al., 2015). It's marked in the list of invasive and potentially invasive species in Siberia (Ebel et al., 2014).

The same chromosome number is known for the Far East and North Caucasus (Rice et al., 2015). We give the first data on chromosome number for Siberia.

Diploid $(2 x), x=7$.

\section{POACEAE}

Lolium multiflorum Lam., $2 n=14$

"Novosibirsk Region, Novosibirsk city, Tereshkova street, in houses' yards, outside lawns and flower beds, $54^{\circ} 50^{\prime} \mathrm{N}, 83^{\circ} 06^{\prime} \mathrm{E} .30$ VII 2017. E. Zykova", 3817-Z492.

Distribution: Eurasian species. It is known in Novosibirsk Region since 1990 (Nikiforova, 1990), found in Novosibirsk city, where the species is currently rather active.

In Siberia $2 n=14$ is defined for Irkutsk Region (Chepinoga et al., 2012) and the Republic of Altai
(Lomonosova et al., 2018). We give the first data on chromosome number for Novosibirsk Region.

Diploid $(2 x), x=7$. Variable ploidy.

\section{Conclusion}

Five of seven active species have variable ploidy: Cota tinctoria, Centaurea jacea, Erigeron canadensis, Lolium multiflorum, two species showed a ploidic increase: octoploid in Astragalus cicer and tetraploid in Centaurea jacea. Others are stable diploids: Silphiodaucus hispidus, Cardamine flexuosa, Raphanus raphanistrum, Sisymbrium officinale, Astragalus falcatus, Lathyrus sylvestris, Oenothera rubricaulis.

\section{Acknowledgements}

The study was carried out in the framework of the scientific program AAAA-A17-117012610055-3 of the Central Siberian Botanical Garden SB RAS.

\section{REFERENCES / ЛИTEPATУРA}

Antipova E. Yu. 2016. Conyza canadensis (L.) Cronq. In: Chyernaya kniga flory Sibiri [Black book of the flora of Siberia]. Novosibirsk: Geo Publ. Pp. 96-102. [In Russian] (Антипова E. Ю. Conyza canadensis (L.) Cronq. - Meлколепестничек канадский // Черная книга флоры Сибири. Новосибирск: Академическое изд-во «Гео», 2016. C. 96-102).

An'kova T. V., Shaulo D. N., Shmakov A. I., Piak A. I. 2013. Chromosome numbers of some species of Magnoliopsida from South Siberia and Kazakhstan. Turczaninowia 16, 3: 84-85. [In Russian] (Анькова Т. В., Шауло Д. Н., Шмаков $\boldsymbol{A}$. И., Пяк $\boldsymbol{A}$. И. Числа хромосом некоторых видов двудольных растений Южной Сибири и Казахстана // Turczaninowia, 2013. Т. 16, № 3. C. 84-85). DOI: 10.14258/turczaninowia.16.3.14

An'kova T. V., Zykova E. Yu. 2017. IAPT/IOPB chromosome date 25 in K. Marhold, J. Kučera (eds.) Taxon 66(5): 1246-1252. URL: https://www.iapt-taxon.org/files/iopb/IAPT_IOPB_Chr_data25.pdf

Breslavets L. P. 1963. Poliploidiya v prirode i opyte [Polyploidy in nature and experience]. Moscow: Izdatelstvo AN SSSR. 364 pp. [In Russian] (Бреславец Л. П. Полиплоидия в природе и опыте. М.: Изд-во АН СССР, 1963. 364 c.).

Chepinoga $\boldsymbol{V}$. $\boldsymbol{V}$. 2014. Chromosome numbers of plant species from Baikal Siberia. Novosibirsk: Nauka. 419 pp. [In Russian] (Чепинога B. В. Хромосомные числа растений флоры Байкальской Сибири. Новосибирск: Наука, 2014. 419 c.).

Chepinoga V. V., Gnutikov A. A., Lubogoshinskiy P. I. 2012. Chromosome numbers of some vascular plant species from the south of Baikal Siberia. Botanica Pacifica 1(1): 127-132. URL: http://www.geobotanica.ru/ bp/2012_01_01/2012_01_chepinoga_s.pdf

Ebel A. L., Strelnikova T. O., Kupriyanov A. N., Anenkhonov O. A., Ankipovich E. C., Antipova E. M., Verkhozina A. V., Efremov A. N., Zykova E. Yu., Mikhaylova S. I., Plikina N. V., Ryabovol S. V., Silantyeva M. M., Stepanov N. V., Terekhina T. A., Chernova O. D., Shaulo D. N. 2014. Invasive and potential invasive species of Siberia. Byull. Glavn. bot. sada (Moscow) [Bulletin of Main Botanical Garden] 1(200): 52-61. [In Russian] (Эбель A. Л., Стрельникова Т. О., Куприянов А. Н., Аненхонов О. А., Анкипович Е. С., Антипова Е. М., Верхозина А. В., Ефремов А. Н., Зыкова Е. Ю., Михайлова С. И., Пликина Н. В., Рябовол С. В., Силантьева М. М., Степанов Н. В., Терехина Т. А., Чернова О. Д., Шауло Д. Н. Инвазионные и потенциально инвазионные виды Сибири // Бюл. Глав. ботан. сада, 2014. № 1 (вып. 200). С. 52-61).

Ebel A. L., Zykova E. Yu., Verkhozina A. V., Chepinoga V. V., Kazanovsky S. G., Mikhailova S. I. 2015. New and rare species in adventitious flora of Southern Siberia. Sist. Zametki Mater. Gerb. Krylova Tomsk. Gosud. Univ. [Systematic notes on the materials of P. N. Krylov Herbarium of Tomsk State University] 111: 16-32. [In Russian] (Эбель А. Л., Зыкова Е. Ю., Верхозина А. В., Чепинога В. В., Казановский С. Г., Михайлова С. И. Новые и 
редкие виды в адвентивной флоре Южной Сибири // Сист. зам. Герб. Томск. ун-та, 2015. № 111. С. 16-32). DOI: 10.17223/20764103.111.2

Efimov K. F. 2005. Chromosome numbers of some species of the families Amaryllidaceae, Asteraceae, Fabaceae in North Ossetia. In: Karyologiya, karyosystematika i moleculyarnaya filogeniay [Karyology, karyosystematics and molecular phylogeny]. St. Petersburg. Pp. 33-35. [In Russian] (Ефимов К. Ф. Число хромосом некоторых видов семейств Amaryllidaceae, Asteraceae, Fabaceae в Северной Осетии // Кариология, кариосистематика и молекулярная филогения. СПб., 2005. С. 33-35).

Efremov A. N. 2016. Velarum officinale (L.) Reichenb. In: Chernaya kniga flory Sibiri [Black book of the flora of Siberia]. Novosibirsk: Geo Publ. Pp. 174-177. [In Russian] (Ефремов A. H. Velarum officinale (L.) Reichenb. Желтец лекарственный // Черная книга флоры Сибири. Новосибирск: Академическое изд-во «Гео», 2016. С. 174-177).

Krasnikov A. A., Korolyuk E. A. 1995. Chromosome numbers in some members of the family Asteraceae from Siberian flora. Bot. Zhurn. (Moscow \& St. Petersburg) 80(4): 107. [In Russian] (Красников А. А., Королюк Е. А. Числа хромосом некоторых представителей семейства Asteraceae флоры Сибири // Бот. журн., 1995. Т. 80, № 4. C. 107).

Lomonosova M. N., Zykova E. Yu., An'kova T. V. 2018. Chromosome numbers of invasive species of the Altai Republic flora. II. Turczaninowia 21, 4: 63-72. DOI: 10.14258/turczaninowia.21.4.7

Magulaev A. Yu. 1980. Chromosome numbers in some Fabaceae in the North Caucasus. Bot. Zhurn. (Moscow \& Leningrad) 65(6): 836-843. [In Russian] (Магулаев А. Ю. Хромосомные числа некоторых бобовых Северного Кавказа // Бот. журн., 1980. Т. 65, № 6. С. 836-843).

Nikiforova O. D. 1990. Lolium L. In: Flora Sibiri [Flora of Siberia]. Vol. 2. Novosibirsk: Nauka. Pp. 162-163. [In Russian] (Никифорова О. Д. Lolium L. - Плевел // Флора Сибири. Т. 2. Новосибирск: Наука, 1990. С. 162-163).

Probatova N. S. 2003. The chromosome numbers as a source of information in studies of the Russian Far East flora. Vestnik DVO RAN 3: 54-67. [In Russian] (Пробатова H. С. Числа хромосом растений как источник информации при изучении флоры Дальнего Востока России // Вестник ДВО РАН, 2003. № 3. С. 54-67).

Probatova N. S., Kazanovsky S. G., Rudyka E. G., Seledets V. P., Nechaev V. A. 2012. IAPT/IOPB chromosome data 13 in K. Marhold (ed.). Taxon 61(4): 889-902. URL: https://www.iapt-taxon.org/files/iopb/IAPT_IOPB_Chr_ data13.pdf

Probatova N. S., Rudyka E. G., Seledets V. P., Nechaev V. A. 2008. IAPT/IOPB chromosome data 6 in Marhold (ed.). Taxon 57(4): 1268-1271. URL: http://www.jstor.org/stable/27756778

Probatova N. S., Sokolovskaya A. P. 1986. Chromosome numbers of the vascular plants from the Far East of the USSR. Bot. Zhurn. (Moscow \& Leningrad) 71(11): 1573. [In Russian] (Пробатова Н. С., Соколовская А. П. Числа хромосом сосудистых растений с Дальнего Востока СССР // Бот. журн., 1986. Т. 71, № 11. С. 1573).

Rice A., Glick L., Abadi S., Einhorn M., Kopelman N., Salman-Minkov A., Mayzel J., Chay O., Mayrose I. 2015. The Chromosome Counts Database (CCDB) - a community resource of plant chromosome numbers. New Phytol. 206(1): 19-25. URL: http://ccdb.tau.ac.il

Rostovtseva T. S. 1983. Cromosome numbers of some species of Asteraceae family. Bot. Zhurn. (Moscow \& Leningrad) 68(5): 660-664. [In Russian] (Ростовцева T. С. Числа хромосом некоторых видов семейства Asteraceae // Бот. журн., 1983. Т. 68, № 5. С. 660-664).

Shaulo D. N., Zykova E. Yu. 2013. Findings of adventive species in the Novosibirsk Oblast. Rastitelnyy Mir Aziatskoy Rossii [Plant Life of Asian Russia] 1(11): 37-43. [In Russian] (Шауло Д. Н., Зыкова Е. Ю. Находки адвентивных видов в Новосибирской области // Растительный мир Азиатской России, 2013. № 1(11). С. 37 43). URL: http://www.izdatgeo.ru/pdf/rast/2013-1/37.pdf

Shaulo D. N., Zykova E. Yu., Drachev N. S., Kuzmin I. V., Doronkin V. M. 2010. Floristic findings in West and Middle Siberia. Turczaninowia 13, 3: 77-91. [In Russian] (Шауло Д. Н., Зыкова Е. Ю., Драчев Н. С., Кузьмин И. В., Доронькин В. М. Флористические находки в Западной и Средней Сибири // Turczaninowia, 2010. Т. 13, № 3. С. 77-91).

Smirnov Yu. A. 1968. Accelerated method for studying somatic chromosomes in fruit trees. Tsitologiya [Cytology] 10(12): 1132-1134. [In Russian] (Смирнов Ю. А. Ускоренный метод исследования соматических хромосом плодовых // Цитология, 1968. Т. 10, № 12. С. 1132-1134).

Soltis D. E., Buggs R. J. A., Dovle J. J., Soltis P. S. 2010. What we still don't know about polyploidy. Taxon 59(5): 1387-1403. URL: https://www.researchgate.net/profile/Richard_Buggs/publication/216492922_What_we_ still_don't_know_about_polyploidy/links/0deec5361075a0eed1000000.pdf

Stebbins G. $\bar{L}$. 1985 . Polyploidy, hybridization, and invasion of new habitats. Annals of the Missouri Botanical Garden 72: 824-832. URL: http://www.biodiversitylibrary.org/item/89033\#page/841/mode/1up

Tonyan C. R. 1968. Chromosome numbers of some species of the genus Centaurea L. Biol. Zhurn. Armenii 21, 5: 86-96. [In Russian] (Тонян Ц. Р. Числа хромосом некоторых видов рода Centaurea L. // Биол. журн. Армении, 1968. T. 21, № 5. C. 86-96). 
Zykova E. Yu. 2016. Centaurea jacea L. In: Chernaya kniga flory Sibiri [Black book of the flora of Siberia]. Novosibirsk: Geo Publ. Pp. 88-91. [In Russian] (Зыкова E. Ю. Centaurea jacea L. - Василек луговой // Черная книга флоры Сибири. Новосибирск: Академическое изд-во «Гео», 2016. С. 88-91). URL: http://www.kuzbs.ru/images/ stories/pdf/izdania/chernaya_kniga_flori_sibiri.pdf

Zykova E. Yu. 2019. Alien flora of the Novosibirsk Region. Acta Biologica Sibirica 5, 4: 127-140. [In Russian] (Зыкова Е. Ю. Адвентивная флора Новосибирской области // Acta Biologica Sibirica, 2019. Вып. 5, № 4. С. 127-140). DOI: 10.14258/abs.v5.i4.7147

Zykova E. Yu., Kleshcheva E. A., Shaulo D. N., Tupitsyna N. N., Shmakov A. I. 2014a. Findings of some rare and adventive plant species in Novosibirskaya Oblast. Turczaninowia 17, 4: 74-78. [In Russian] (Зыкова Е. Ю., Клещева Е. А., Шауло Д. Н., Тупицына Н. Н., Шмаков А. И. Находки редких и заносных видов сосудистых растений в Новосибирской области // Turczaninowia, 2014. Т. 17, № 4. С. 74-78). DOI: 10.14258/turczaninowia.17.4.13

Zykova E. Yu., Korolyuk A. Yu., Korolyuk E. A., Lashchinskiy N. N. 2014b. High vascular plants. In: Rastitelnoye mnogoobraziye Tsentralnogo sibirskogo botanicheskogo sada SO RAN [Plant diversity of the Central Siberian botanical garden SB RAS]. Novosibirsk: Geo Publ. Pp. 318-437. [In Russian] (Зыкова Е. Ю., Королюк А. Ю., Королюк $\boldsymbol{E}$. A., Лащинский $\boldsymbol{H}$. H. Высшие сосудистые растения // Растительное многообразие Центрального сибирского ботанического сада СО РАН. Новосибирск: Академическое изд-во «Гео», 2014. С. 318-437).

Zykova E. Yu., Lomonosova M. N., An'kova T. V. 2018. Chromosome numbers of invasive species of the Altai Republic flora: post 1. Turczaninowia 21, 1: 41-51. [In Russian] (Зыкова Е. Ю., Ломоносова М. Н., Анькова Т. В. Числа хромосом инвазионных видов во флоре Республики Алтай: сообщение 1 // Turczaninowia, 2018. Т. 21, № 1. C. 41-51). DOI: 10.14258/turczaninowia.21.1

Zykova E. Yu., Shemetova T. A. 2018. Findings of adventive species in Novosibirsk Oblast. Bull. Moscow Soc. Natur. Biol. Ser. 123, 6: 66-68. [In Russian] (3ыкова E. Ю., Шеметова T. А. Находки адвентивных видов в Новосибирской области // Бюл. МОИП. Отд. биол., 2018. Т. 123, вып. 6. С. 66-68). 